\title{
Two Examples of Inefficient Use of Public Finances in Poland
}

\author{
Valery Okulich-Kazarin ${ }^{1,2, *}$ \\ ${ }^{1}$ East European Scientific Group, Czestochowa, Poland \\ ${ }^{2}$ Department of Applied Economics and Management of Odessa University of Food Technologies, Odessa, Ukraine
}

Received July 15, 2021; Revised August 19, 2021; Accepted September 23, 2021

\section{Cite This Paper in the following Citation Styles}

(a): [1] Valery Okulich-Kazarin , "Two Examples of Inefficient Use of Public Finances in Poland," Universal Journal of Accounting and Finance, Vol. 9, No. 5, pp. 1024 - 1032, 2021. DOI: 10.13189/ujaf.2021.090513.

(b): Valery Okulich-Kazarin (2021). Two Examples of Inefficient Use of Public Finances in Poland. Universal Journal of Accounting and Finance, 9(5), 1024 - 1032. DOI: 10.13189/ujaf.2021.090513.

Copyright@2021 by author, all rights reserved. Author agrees that this article remains permanently open access under the terms of the Creative Commons Attribution License 4.0 International License

\begin{abstract}
The background of the research is that scientists and practitioners are interested in the efficiency of the use of public finances. There are articles about financial management processes in the form of planning, implementation and reporting as elements of good governance of public finances. The aim of this empirical research was to check: do Polish officials effectively make use of public finances? The author has used justified research methods such as general scientific research methods (methods of analysis and synthesis, induction and deduction, etc.); study of scientific sources and official documents; observation with recording the results using photography; statistical methods, including verification of statistical hypotheses. In the first example, the use of public finance in a state-owned enterprise was carefully studied. In the second example, the author described the use of public finance at the local level. The empirical research had only one limitation: the inefficient use of public finances is usually hidden from citizens. The key hypothesis: the Polish officials effectively use of public finances. These examples did not allow us to accept the Key Hypothesis. The principal result of the empirical research is that the facts of inefficiency of the use of public finance in Poland have become a new scientific knowledge. Modern statistics allow us to attribute the results of the sample to the entire population. The major conclusions and its contributions to the field of public finances are in the facts: A) Polish officials use public finance inefficiently both at state-owned enterprises and at the local level. B) The inefficient use of public finance was five years ago and continues now. The result is highly statistically significant
\end{abstract}

(99.0\%). The inefficient use of public finances has serious negative social consequences: economic, budgetary, legal and psychological. The most important aspects of the empirical research are in practical and theoretical significance. In the practical significance, it is necessary to create working bodies for checking the efficiency of the use of public finances. In the theoretical significance, it is very important to create financial mechanisms that stimulate the effective use of public finances.

Keywords Public Finance, Efficiency, Financial Management, Financial Mechanisms, Officials, Poland

\section{Introduction}

The Universal Journal of Accounting and Finance has published the article [1] about financial management processes in the form of planning, implementation and reporting as an element of good governance. This study has implications for the high-quality management processes of finance (planning, implementation and reporting) and ending with increasing public confidence in the level of accountability of village officials [1]. However, the public confidence for officials is also relevant for officials of government bodies and other institutions receiving public finances.

The author of the research has analyzed two examples of the use of public finance in Poland.

The research's aim is to check the efficiency of the use 
of public finances in Poland. So, this research is empirical.

The following research methods were used:

- general scientific research methods such as methods of analysis and synthesis, induction and deduction;

- $\quad$ study of scientific sources and official documents;

- observation with recording the results using photography;

- statistical methods, including verification of statistical hypotheses.

When the author checked the efficiency of the use of public finances for scientific purposes among university teachers at a Polish state university, it was statistically proven that the difference between the amount of public finance for research received by the officials and the amount received by any of the university teachers does not lie within the statistical deviations. It was proved that the officials of the university are not outstanding scientists and they used public finance inefficiently.

In the second example, it was checked the efficiency of the use of public finance by the local government in the Polish city of N. Therefore, we claim that we met the fact the local government used the public finances ineffective.

So, we don't accept the key hypothesis: the Polish officials ensure the effective use of public finances. We accept two facts of inefficient use of public finances.

The results of the empirical research are of practical and theoretical importance for Polish governments and public institutions.

From the theory of financial management point of view it is interesting to improve control over the use of public finance. It's very important to create financial mechanisms that stimulate the effective use of public finances.

From a psychological point of view it is interesting to find out why the Polish population agrees with the facts of inefficient use of public finances.

From a legal point of view it is interesting to understand how to change the Constitution of Poland and other legal acts in order to introduce criminal and other liability for the ineffective use of public finances.

The results are also important for Polish citizens.

\section{Literature Review}

Scientists and practitioners all over the world are interested in the efficiency of the use of public finance. This topic is of interest in Asia [2], in the European Union [3], in Russia [4], in Canada and in the USA [5, 6].

In the book [7], the analysis of the efficiency of the functioning of public finance is carried out using the traditional theory of public finance and the theory of public choice.

The efficiency of projects and programs, any socially significant innovations, especially those implemented at the taxpayer's expense, is the most important object of attention of public control.

The concept of financial policy, focused on the transition from cost management to results management, defines a new approach to assessing the efficiency of the use of public finance. This is a more complex problem compared to the commercial sector, since in addition to economic efficiency, it is necessary to evaluate numerous social, scientific, environmental and other components of the efficiency of spending public finances.

For example, back in 2006, the President of the Russian Federation in his address to the Federal Assembly noted that budget policy should be formed based on solving the problems of macroeconomic balance and improving the efficiency of public finance management [4].

In the article [2], it is required, in particular, to reform local authorities in the field of the use of public finance.

The article [8] shows that the quality of the internal control system and the quality of financial information are the determining factors for the success of decision-making [8].

The Polish Criminal Code does not contain responsibility for the illegal or inefficient use of public finances [9]. And, even, the Polish Tax Code does not contain the concepts of "tax crime" and "tax offense" [10].

In the list of Codes in force in Polish legislation, there are no such Codes as the Financial Code or the Budget Code.

Thus, there are no mechanisms of legal control over the effectiveness of the use of public finance in Poland. Although, in developing and developed countries, the importance of effective use of public finance is recorded in the scientific literature and official state documents.

As a short review of the literature showed, despite the importance of the effective use of public finance, there is no legal framework for controlling the efficiency of the use of public finance in Poland.

We can assume that the moral values and the high level of professionalism of Polish officials ensure the effective use of public finances always and everywhere.

This empirical research deals with two examples of inefficient use of public finances in Poland.

\section{Methods}

\subsection{Total Information}

This empirical research was carried out since February 2016 till June 2021.

The author used the following research methods:

- general scientific research methods (methods of analysis and synthesis, induction and deduction);

- $\quad$ study of scientific sources and official documents;

- observation with recording the results using photography;

- statistical methods [11], including verification of statistical hypotheses [12].

The research question is do Polish officials effectively use of public finances? 
The aim of this empirical research is to check: do Polish officials effectively use of public finances?

The aim was transformed into two research tasks that were explored sequentially:

1. It is investigation how public finances of state-owned enterprises and organizations are used.

2. It is investigation how local finances are used.

The key hypothesis is that the Polish officials effectively use of public finances.

The object of the research is the public finance.

The subject of the study is efficiency of use public finances in Poland.

\subsection{Plan of the Research}

The research was carried out in the form of studying two examples:

- It is investigation how public finances of state-owned enterprises and organizations are used.

- It is investigation how local finances are used.

At the same time, the study was performed at different times, in the past and in the present. This allowed us to see the situation with the efficiency of the use of public finance in dynamics. The empirical research had only one limitation: the inefficient use of public finances is usually hidden from citizens.

In the first example, the efficiency of the use of public finance at a Polish University was checked. This example was studied in 2016-2020.

The first example was studied in three stages:

- $\quad$ First, it was studied the distribution of public finances for scientific purposes among university teachers at a Polish state university. They were employees of one department of the state university. They researched one scientific field and published their papers in one scientific field.

- Second, it was studied the publication activity of these same employees.

- At the third stage, statistical hypotheses were formulated and verified. The methodology of statistical research is borrowed from the source [12]. It was estimated the difference between two mathematical expectations. The Null hypothesis was verified: the unknown means for a group of officials and the unknown means for a group of university teachers are equal to each other.

In the second example, the efficiency of the use of public finance by the local government in the Polish city of N. was checked. It was in 2021.

\subsection{Verification of Statistical Hypotheses}

The author verified the statistical hypotheses according to the statistical textbook [12]. The verification of statistical hypotheses made it possible to transform the information of the official documents into new objective research knowledge [12].

After discussions, the conclusions were made by the author.

\section{Results}

\subsection{Theoretical Brief}

In the theory of public finance, the foundations of effective resource allocation were laid by V. Pareto [7].

Public finance is a system of redistributive monetary relations regulated by the state, related to the formation and use of centralized (public) monetary funds (income) necessary for the state to perform its functions [13]. The financial system includes three parts [14]:

- national finance;

- local finance;

- finance of state-owned enterprises and organizations.

Our first example concerns state-owned enterprises and organizations. The second example refers to local finance.

Measuring the efficiency of various activities is necessary to compare the achieved result and the accepted standard, "potential". And also the measurement of efficiency is necessary for comparison with previously achieved results [15].

There are two definitions [16, p. 142]:

- Effectiveness is the ability to achieve the set goals,

- Efficiency is the optimal ratio of the resources spent and the results obtained.

Further in the study, the author uses the definition of "efficiency".

Social efficiency is considered as the ratio of the obtained favorable social results to the costs of achieving them [17]. This study checks the social efficiency of the use of public finance.

From the set of methods recommended for measuring the efficiency of public spending, the "comparison" method will be used in this study [15].

This study covered the ratio of the achieved result of use of public finances and the potential of their use.

In both examples, the comparison of the obtained result when using public finance and the potential result is performed.

\subsection{The First Example: Distribution of Public Finances for Scientific Purposes}

Here we are talking about public finance for scientific purposes. These public finances are not wages. These are additional public finances with a specific purpose [18]. This goal is scientific research, the results of which are evaluated by publications.

Table 1 shows the university teachers who got public finances in the number of 11 people, according to the recommendations from the book [11]. There were 
professors, associate professors and assistant among them.

Table 1. Distribution of public finances for scientific purposes (publication of papers), 2016

\begin{tabular}{|c|l|c|}
\hline No & Person receiving funds & Amount, zlotys \\
\hline \multicolumn{2}{|l|}{ Officials } \\
\hline 1 & $\begin{array}{l}\text { Director of the Institute, Associate } \\
\text { professors, Dr }\end{array}$ & 7500 \\
\hline 2 & $\begin{array}{l}\text { Deputy Director of the Institute for } \\
\text { Scientific Work, Professor, Dr. Habil }\end{array}$ & 8000 \\
\hline 3 & $\begin{array}{l}\text { Deputy Director of the Institute on } \\
\text { Student Affairs, Assistant }\end{array}$ & 4500 \\
\hline 4 & Total & 20000 \\
\hline 5 & The expected value, $\dot{X}$ & $\mathbf{6 6 6 6 . 7}$ \\
\hline 6 & The standard deviation for the sample, $\delta_{\mathrm{x}}$ & 1545.6 \\
\hline University teachers & 3500 \\
\hline 7 & Professor, Dr. Habil & 5500 \\
\hline 8 & Associate professors, Dr & 5500 \\
\hline 9 & Associate professors, Dr & 5000 \\
\hline 10 & Associate professors, Dr & 3500 \\
\hline 11 & Associate professors, Dr & 3000 \\
\hline 12 & Associate professors, Dr & 3000 \\
\hline 13 & Associate professors, Dr & 3000 \\
\hline 14 & Associate professors, Dr & $\mathbf{4 0 0 0 . 0}$ \\
\hline 15 & Total & 1060.7 \\
\hline 16 & The expected value, $\dot{X}$ & \\
\hline 17 & The standard deviation for the sample, $\delta_{x}$ & \\
\hline
\end{tabular}

Table 1 shows that the three officials received a total of 20,000 zlotys. Among the officials there are one professor, one associate professor and one assistant. The expected value $(\dot{\mathrm{X}})$ of public finance received per official is 6666.7 zlotys.

Eight other university teachers received a total of 32,000 zlotys. They include one professor and seven associate professors. In other words, their average scientific qualification is higher than that of officials. The expected value $(\dot{\mathrm{X}})$ of public finances received by one person is 4000.0 zlotys. This is 1.67 times less per person than for officials.

Thus, the officials assigned themselves public finance for scientific research 1.67 times more than they assigned public finance for the university teachers.

What is the reason for this decision? What is its foundation? Did the officials turn out to be outstanding scientists and their scientific results are 1.67 times higher than those of the university teachers? Is this the result of random deviations in the size of public finances allocated to a person? Or is this decision an inefficient use of public finances?

Below it will be checked whether the officials are outstanding scientists and their scientific results are 1.67 times higher than those of the university teachers?

\subsection{The First Example: Distribution of Publications among the Members of this Team}

Based on the goal of effective use of public finances, we should expect that these officials, having received more public finances for scientific research, will publish 1.67 times more publications than the university teachers. In this case, we can talk about the effective use of public finances by officials.

Table 2 shows the efficiency of using additional public finances [18] for scientific purposes. Here is the number of publications in 2016, as a result of scientific activity [19]. The position of each member of this team in Table 2 corresponds to its position in table 1.

Table 2. Distribution of publications, 2016

\begin{tabular}{|c|c|c|}
\hline No & Person receiving funds & Amount \\
\hline \multicolumn{3}{|c|}{ Officials } \\
\hline 1 & $\begin{array}{l}\text { Director of the Institute, Associate professors, } \\
\text { Dr }\end{array}$ & 12 \\
\hline 2 & $\begin{array}{l}\text { Deputy Director of the Institute for Scientific } \\
\text { Work, Professor, Dr. Habil }\end{array}$ & 4 \\
\hline 3 & $\begin{array}{l}\text { Deputy Director of the Institute on Student } \\
\text { Affairs, Assistant }\end{array}$ & 6 \\
\hline 4 & Total & 22 \\
\hline 5 & The expected value, $\dot{X}$ & 7.3 \\
\hline 6 & The standard deviation for the sample, $\delta_{\mathrm{x}}$ & 3.4 \\
\hline \multicolumn{3}{|c|}{ University teachers } \\
\hline 7 & Professor, Dr. Habil & 27 \\
\hline 8 & Associate professors, Dr & 19 \\
\hline 9 & Associate professors, Dr & 6 \\
\hline 10 & Associate professors, Dr & 12 \\
\hline 11 & Associate professors, Dr & 6 \\
\hline 12 & Associate professors, Dr & 18 \\
\hline 13 & Associate professors, Dr & 2 \\
\hline 14 & Associate professors, Dr & 2 \\
\hline 15 & Total & 92 \\
\hline 16 & The expected value, $\dot{X}$ & 11.5 \\
\hline 17 & The standard deviation for the sample, $\delta_{\mathrm{x}}$ & 8.5 \\
\hline
\end{tabular}

Table 2 shows the expected value $(\dot{X})$ of publications per official is 7.3. At the same time, the expected value $(\dot{X})$ of publications per university teacher is 11.5 .

Table 2 has really proved the officials are not outstanding scientists if their scientific results are not 1.67 times higher than those of the university teachers.

The average cost per publication is equal to 909.1 zlotys for officials. The average cost per publication is equal to 347.8 zlotys for university teachers.

The average cost of one publication for the officials was 2.6 times higher than that of the university teachers. This is an inefficient use of public finance by the officials, if it is not the result of random deviations.

The purpose of the next stage is to test hypothesis, that the unknown means for the group of the officials and the unknown means for the group of the university teachers are equal to each other.

\subsection{The First Example. The Verification of Statistical Hypotheses: The Means of the Public Finances Received by Officials and University Teachers for Research Are Equal}

The verification of hypothesis allows getting new 
objective research knowledge about use of public finance by officials and university teachers in Poland.

A couple of statistical hypotheses were compiled for the verification.

The Null hypothesis: the unknown means for the group of the officials and the unknown means for the group of the university teachers are equal to each other. In other words, the difference between the amount of public finance for research received by the officials and the amount received by any of the university teachers lies within the statistical deviations.

The Null hypothesis is $\mathrm{H}_{0}: \mu_{1}-\mu_{2}=0.0$.

The Null hypothesis asserts that the amounts of public finances for research received by the officials and the university teachers are equal, if random deviations are not taken into account.
The Alternative hypothesis: the unknown means for the group of the officials and the unknown means for the group of the university teachers are not equal to each other. In other words, the difference between the amount of public finance for research received by the officials and the amount received by any of the university teachers does not lie within the statistical deviations.

The Alternative hypothesis is $\mathrm{H}_{1}: \mu_{1}-\mu_{2} \neq 0.0$.

The Alternative hypothesis asserts that the amounts of public finances for research received by the officials and the university teachers are not equal, if random deviations are not taken into account.

The author estimated the difference between two mathematical expectations $\dot{\mathrm{X}}_{1}$ and $\dot{\mathrm{X}}_{2}$ at a level of significance of 99.0. Table 3 presents the calculation results.

Table 3. The verification of statistical hypotheses: the unknown means for a group of officials and the unknown means for a group of university teachers are equal to each other. The checking level is $1,0 \%$

\begin{tabular}{|c|c|c|c|}
\hline № & Indicator & officials & University teachers \\
\hline 1 & the size of a sample, $n$ & 3 & 8 \\
\hline 2 & the expected value, $\dot{X}$ & 6666.7 & 4000.0 \\
\hline 3 & $\dot{X}_{1}-\dot{X}_{2}$ & \multicolumn{2}{|c|}{2666.7} \\
\hline 4 & $\mu_{1}-\mu_{2}$ & \multicolumn{2}{|c|}{0.00} \\
\hline 5 & the standard deviation for the sample, $\delta_{\mathrm{x}}$ & 1545.6 & 1060.7 \\
\hline 6 & average error, $\dot{S}_{\dot{X}}=\delta_{x} / V_{n}$ & 892.4 & 375.0 \\
\hline 7 & $\dot{\mathrm{S}}_{\mathrm{x}}^{2}$ & 796377.8 & 140630.3 \\
\hline 8 & $\dot{\mathrm{S}}_{1}{ }^{2}-\dot{\mathrm{S}}_{2}{ }^{2}$ & \multicolumn{2}{|c|}{655747.5} \\
\hline 9 & $\sqrt{ }\left(\dot{\mathrm{S}}_{1}^{2}-\dot{\mathrm{S}}_{2}^{2}\right)$ & \multicolumn{2}{|c|}{809.8} \\
\hline 10 & $\left|z_{\text {stat }}\right|=\left[\left(\dot{X}_{1}-\dot{X}_{2}\right)-\left(\mu_{1}-\mu_{2}\right)\right] / \sqrt{ }\left(\dot{\mathrm{S}}_{1}^{2}-\dot{\mathrm{S}}_{2}^{2}\right)$ & \multicolumn{2}{|c|}{3.29} \\
\hline 11 & the value $z_{\text {tabl }}$ for the level of significance 99,0 & \multicolumn{2}{|c|}{2.58} \\
\hline 12 & Result, $\left|z_{\text {stat }}\right|<\left|z_{\text {table }}\right|$ & \multicolumn{2}{|c|}{ No } \\
\hline 13 & The accepted hypothesis & \multicolumn{2}{|c|}{ Alternative } \\
\hline
\end{tabular}


For the standard significance level of $99 \%(\mathrm{p}=0.01)$, $\mathrm{z}_{\text {tabl }}=2.58$ [12]. In our case, $\left|\mathrm{z}_{\text {stat }}\right|=3.29$. Table 2 shows that $z_{\text {tabl }}$ is less than $\left|z_{\text {stat }}\right|$. So, the Alternative hypothesis is accepted: the unknown means for the group of the officials and the unknown means for the group of the university teachers are not equal to each other. In other words, the difference between the amount of public finance for research received by the officials and the amount received by any of the university teachers does not lie within the statistical deviations.

It was statistically proven that the amounts of public finances for research received by the officials and the university teachers are not equal, if random deviations are not taken into account.

The obtained result is highly statistically significant (99.0\%).

In this particular case, the provider of educational services represented by university teachers receives less public finances for research as a result of an unfair and unjustified decision of officials. This has negative economic and social consequences. At first, this leads to a decrease in the scientific qualifications of university teachers. After that, it leads to a decrease in the quality of educational services.

\subsection{The Second Example: The Efficiency of the Use of Public Finance by the Local Government}

Here we are talking about public finance for municipal purposes. We are considering an example of using public finance by the local government in the Polish city of $\mathrm{N}$. This was in the spring of 2021. This part of the research was performed using general scientific research methods and observation with recording by photography way.

This example concerns the arrangement of a children's summer playground in the courtyard of the house where the author lives. This playground can be seen from the window.

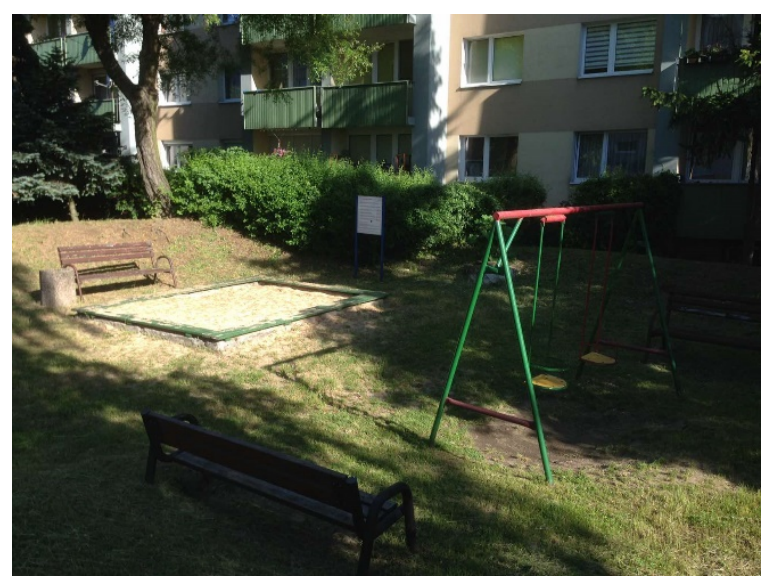

Photo 1. The old sandbox, April 2021

For several years, there was a sandbox with sand on this playground. Every spring, the local government changed the sand in the sandbox. The children played in this sandbox. The sandbox had a concrete foundation and a square shape (Photo 1).

Then suddenly and unexpectedly, the local government has decided to reform this sandbox.

The former sandbox was dismantled. A new sandbox was built instead. It has the same concrete foundation and ... a round shape (Photo 2).

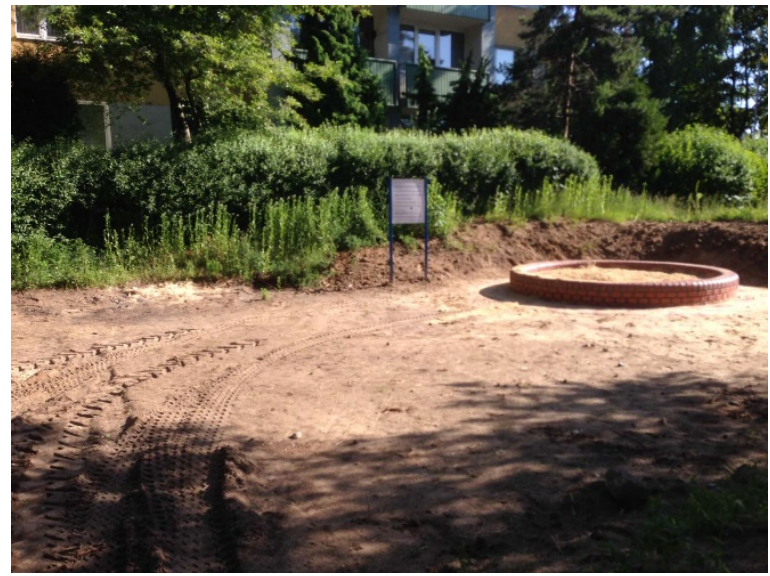

Photo 2. The new sandbox, May 2021

Are there more children playing in the new sandbox? No, there are no more children, because there are no more children in our house. Has it become more fun for children to play in the new sandbox? I'm not sure.

But everyone is sure that public finances were spent:

1. for dismantling the old sandbox,

2. for building a new sandbox.

And these expenses of public finances brought only one result: the shape of the sandbox was changed from square to round. And its green color has changed to brick.

Comparing the new result with the previously achieved one [15], we cannot see any reasons justifying the costs of reforming the sandbox for children.

As a professor at the School of Entrepreneurship, I believe that these costs of public finance were ineffective. This has negative economic and social consequences. These public finances could be spent, for example, on the prevention of such a dangerous disease as COVID-19 on the territory of the city of N. [20,21].

\section{Discussion}

What did the results of the research show?

First, it was studied the distribution of public finances for scientific purposes among the officials and the university teachers at a Polish state university. They were employees of one department of the state university. They researched one scientific field and published their papers in one scientific field. It was shown that the officials assigned themselves public finance for scientific research 1.67 times 
more than they assigned public finance for the university teachers.

It was hypothesized three reasons explaining this fact:

a) The officials turned out to be outstanding scientists and their scientific results were 1.67 times higher than those of the university teachers.

b) It is the result of random deviations in the size of public finances allocated to a person.

c) This is an inefficient use of public finances.

This is a scientific article, so the author did not put forward such versions as: it was an abuse of official powers; it was the use of official position for selfish purposes or it was the theft of public finances.

Second, it was studied the publication activity of these officials and these university teachers. The average cost of one publication for the officials was 2.6 times higher than that of the university teachers.

It was revealed the expected value $(\dot{X})$ of publications per official is 7.3. At the same time, the expected value $(\dot{X})$ of publications per university teacher is 11.5 . This proves that the officials are not outstanding scientists if their scientific results are not 1.67 times higher than those of the university teachers.

Perhaps, this is an inefficient use of public finance by the officials, if it is not the result of random deviations.

Third, it was estimated the difference between two mathematical expectations. The Null hypothesis was verified: the unknown means for the group of the officials and the unknown means for the group of the university teachers are equal to each other.

It has resulted that the Alternative hypothesis was accepted: the unknown means for the group of the officials and the unknown means for the group of the university teachers are not equal to each other.

It was statistically proven that the difference between the amount of public finance for research received by the officials and the amount received by any of the university teachers does not lie within the statistical deviations.

So, in the first example, we have got the third version: this is an inefficient use of public finances.

In this particular case, this leads to a decrease in the scientific qualifications of university teachers. After that, it leads to a decrease in the quality of educational services.

In the second example, it was checked the efficiency of the use of public finance by the local government in the Polish city of $\mathrm{N}$. We saw that the local government unreasonably reformed the sandbox on the playground. In fact, public finances were buried in the ground without any social effect. This fact has negative economic and social consequences. During the COVID-19 pandemic, these public finances could have been used to prevent COVID-19 diseases. Therefore, we claim that we met the fact the local government used the public finances ineffective in the Polish city of N. So, we have received another fact of inefficient use of public finances.

The major conclusions and its contributions to the field of public finances are in the facts that the Polish officials don't ensure the effective use of public finances. This was shown:

1. One fact of inefficient use of public finance was in 2016. The second fact of the inefficient use of public finances was in 2021. This means that the socio-economic and political development of Poland has not eliminated the hidden reasons for the inefficient use of public finances.

2. One fact of inefficient use of public finance was in state-owned organizations. The second fact of the inefficient use of public finances was in the local level. This means that there are no public and other controls for the efficient use of public finances [9, 10].

3. Officials ineffectively use public finances with the tacit consent of university teachers, in the first example, and the citizens, in the second example. As shown in article [22], Polish students are not subject of educational services. Can it be that the citizens of Poland are not subject of public control over the use of public finances?

4. Is it possible to assert on the basis of the empirical research that the inefficient use of public finances takes place everywhere and regularly in Poland? On the basis of the empirical research we are not able to assert that the inefficient use of public finances takes place everywhere and regularly in Poland. At the same time, we came across two facts of inefficient use of public finances. And we have no reason to believe that this does not happen everywhere and regularly in Poland.

Inefficient use of public finances has serious economic and social consequences. First of all, this is the weakened impact of financial incentives on Poland's economic growth. The second is a slowdown in economic growth and a decline in budget revenues. Third, it is a violation of the rights of citizens and the formation of an unhealthy psychological atmosphere in society.

The empirical research had only one limitation: the inefficient use of public finances is usually hidden from citizens. For this reason, it is difficult to draw a complete picture of the use of public finances.

Concluding the checking the key hypothesis, we cannot accept the key hypothesis: the Polish officials ensure the effective use of public finances. We accept two facts of inefficient use of public finances.

The principal result of the empirical research is that the facts of inefficiency of the use of public finance in Poland has become a new scientific knowledge. Modern statistics allow us to attribute the results of the sample to the entire population. Before that, people could guess that officials use public finances inefficiently. And they might not even have guessed this.

The results are of practical and theoretical importance for governments and public institutions.

In the practical part, this empirical research is important: 
1. The results of the research are the basis for checking these two particular cases of inefficient use of public finances. This can be a start for the creation of working bodies for checking the efficiency of the use of public finances. Such working bodies should respond to any sources of information. They must have the competency to transfer the verification materials to the Court and the Prosecutor's Office.

2. The new knowledge gained is of interest and can be used, for an example, in the accounting and finance training in universities [23].

In theoretical terms, this empirical research is a prerequisite for further research in three directions:

1. It is interesting to find out from a psychological point of view why the Polish population agrees with the facts of inefficient use of public finances.

2. It is interesting to understand from a legal point of view how to change the Constitution of Poland and other legal acts in order to introduce criminal and other liability for the ineffective use of public finances. The theoretical justification of such changes in legislation can become an innovation not only in Poland, but also in other countries of the European Union.

3. It is interesting and important from the theory of financial management point of view, to detail and improve control over the use of public finance. It is very important to create financial mechanisms that stimulate the effective use of public finances.

\section{Conclusions}

The author has achieved the aim of this empirical research - he has checked: do Polish officials effectively use of public finances?

When the author checked the efficiency of the use of public finances for scientific purposes among university teachers at a Polish state university, the alternative hypothesis was accepted: the unknown means for the group of the officials and the unknown means for the group of the university teachers are not equal to each other. It was statistically proven that the difference between the amount of public finance for research received by the officials and the amount received by any of the university teachers does not lie within the statistical deviations. It was proved that the officials of the university are not outstanding scientists and they used public finance inefficiently. The result is highly statistically significant (99.0\%).

In the second example, it was checked the efficiency of the use of public finance by the local government in the Polish city of N. Therefore, we claim that we met the fact the local government used the public finances ineffective.

Inefficient use of public finances has serious economic and social consequences.

Summing up this empirical research, let's focus on three new results and one of the tasks of the previous study:

1. So, the key hypothesis was checked by the author. We cannot accept the key hypothesis: the Polish officials ensure the effective use of public finances. The results of this empirical research are of practical and theoretical importance for Polish governments and public institutions.

2. In the practical importance it is recommended to create working bodies for checking the efficiency of the use of public finances.

3. In theoretical terms, this empirical research is a prerequisite for further research in three directions:

A. From a psychological point of view it is interesting to find out why the Polish population agrees with the facts of inefficient use of public finances.

B. From a legal point of view it is interesting to understand how to change the Constitution of Poland and other legal acts in order to introduce criminal and other liability for the ineffective use of public finances.

C. From the theory of financial management point of view it is interesting to improve control over the use of public finance. It's very important to create financial mechanisms that stimulate the effective use of public finances.

4. An inspection of the state-owned organization and local self-government body was carried out. The task of the next stage of the study is to check how effectively national finance is used.

\section{Acknowledgements}

The study was carried out with the assistance of the East European Scientific Group. The author thanks reviewers for their useful comments.

\section{REFERENCES}

[1] B. Pangayow, K. Patma, Planning, Accountability and Reporting of Village Financial Management in Indonesia, Universal Journal of Accounting and Finance, 9(2), 197 - 203, 2021. DOI: 10.13189/ujaf.2021.090208

[2] M. G. Rao, Public Finance in Pandemic Times, Journal of Asian Development Research, 1(1), 1-14, 2021.

[3] C. F. D. Bo, E. Sirtori, Additionality and regional public finance - Evidence from Italy, Environment and Planning C: Politics and Space, 34(5), 855-878, 2015.

[4] On Budget Policy in 2007, Budget Message of the President of the Russian Federation to the Federal Assembly of the Russian Federation, 30.05.2006.

[5] M. M. Edwards, Public Finance in Planning Education and 
Practice, Journal of Planning Education and Research, 27(2), 217-227, 2007.

[6] D. E. Wildasin, Disaster Policies: Some Implications for Public Finance in the U.S. Federation, Public Finance Review, 36(4), 497-518, 2008.

[7] S. V. Kadomtseva, State finance: Textbook, Moscow: INFRA-M, 352, 2009.

[8] A. P. M. Monteiro, J. A. M. Vale, C. L. M. Cepêda, E. M. de Almeida Leite, Internal Control System Quality and Decision-Making Success: The Role of the Financial Information Quality, Universal Journal of Accounting and Finance, 9(3), $285 \quad$ - 294, 2021. DOI: 10.13189/ujaf.2021.090302

[9] Dz.U.2020.0.1444 t.j. - Ustawa z dnia 6 czerwca 1997 r. Kodeks karny, 2020.

[10] Dz.U.2020.0.19 t.j. - Ustawa z dnia 10 września 1999 r. Kodeks karny skarbowy, 2020.

[11] A. I. Kravchenko, Sociologia: textbook for students, M.: Yurayt, 2014.

[12] Textbook for the Program "Masters of Business Administration". BUS_9641_Business_Statistics_3, USA, NY, Kingston University, 2009.

[13] Finance, money circulation and credit: Textbook / M. V. Romanovsky, et al.,; Edited by M. V. Romanovsky, O. V. Vrublevskaya. - M.: Yurayt-Izdat, 543, 2006.

[14] Finance and the financial system of the State: textbook / N. Y. Isakova, Yu. A. Dolgikh, A. G. Lachikhina-2nd ed., reprint. and add. - Yekaterinburg: Ural Publishing House, 2019-124 p.
[15] S. Y. Platoshechkina, On the assessment of the effectiveness of the use of public expenditures, Scientific notes: Economics and Finance, 3, 2009.

[16] T. V. Antipova, N. V. Fadeikina, Evaluation of the effectiveness of the activities of budget recipients-subjects of the public administration sector, Scientific and practical journal "Siberian Financial School". 5/70, 141-146, 2008.

[17] The Big Economic Dictionary / / edited by Borisov A. B., Moscow, Book World, 2009.

[18] Research projects of DS.2016 are implemented within the framework of a grant for statutory activities. The Faculty of Philology and History, 2016.

[19] Public view of author profile. https://pbn.nauka.gov.pl/centr um-pomocy/baza-wiedzy/widok-publiczny-profilu-autora/

[20] WHO (11 March), Director-General's opening remarks at the media briefing on COVID-19, 2020. Retrieved from https://www.who.int/dg/speeches/detail/who-director-genera l-s-opening-remarks-at-the-media-briefing-on-covid-19---11 -march-2020

[21] Q. Li, et al., Early transmission dynamics in Wuhan, China, of novel coronavirus-infected pneumonia, New England Journal of Medicine, 382(13), 1199-1207, 2020.

[22] V. Okulich-Kazarin, Are Students of East European Universities Subjects of Educational Services? Universal Journal of Educational Research, 8(7), 3148-3154, 2020. DOI: 10.13189/ujer.2020.080743

[23] N. Akbulaev, I. Mammadov, S. Shahbazli, Accounting Education in the Universities and Structuring According to the Expectations of the Business World, Universal Journal of Accounting and Finance, 9(1), 130 - 137, 2021. DOI: 10.13189/ujaf.2021.090114 